\title{
Unequal Impact of Price Changes in Indonesia
}

\author{
Rulyusa Pratikto ${ }^{a, *}$, Mohamad Ikhsan ${ }^{\mathrm{b}}$, B. Raksaka Mahi ${ }^{\mathrm{b}}$ \\ ${ }^{a}$ Business Administration Department, Parahyangan Catholic University \\ ${ }^{b}$ Faculty of Economics and Business, Universitas Indonesia
}

\begin{abstract}
The main idea of this study is to determine the impact of relative inflation on poverty incidents and to investigate whether inflation inequality has occurred in Indonesia. Interesting results were found at regional level. Firstly, Jakarta had different poverty response with respect to price increases. Processed food and transportation inflation were more imperative for the poor in Jakarta. Secondly, the poor in province with low poverty figures were more prone to inflation. In general, the results show that food inflation has the major adverse impact on the poor. Moreover, we found that inflation in Indonesia has not been pro-poor.

Keywords: Poverty; Inflation; Price Elasticity of Poverty; Pro-Poor Price Index, Price Index for The Poor
\end{abstract}

\begin{abstract}
Abstrak
Tujuan utama dari penelitian ini adalah untuk menentukan dampak dari perubahan harga terhadap kemiskinan, serta juga untuk mengetahui apakah terjadi ketimpangan inflasi di Indonesia. Hasil yang menarik diperoleh dari analisa pada tingkat provinsi. Pertama, kemiskinan pada provinsi Jakarta memiliki karakteristik yang berbeda. Inflasi pada makanan jadi dan transportasi justru memiliki dampak yang lebih merugikan masyarakat miskin. Kedua, masyarakat miskin yang berada di provinsi dengan tingkat kemiskinan relatif rendah justru lebih sensitif terhadap inflasi. Secara umum, inflasi bahan makanan merupakan faktor terbesar dalam peningkatan kemiskinan. Selain itu, masyarakat miskin telah mengalami total inflasi yang lebih besar dibandingkan dengan masyarakat tidak miskin.

Kata kunci: Kemiskinan; Inflasi; Elastisitas Harga terhadap Kemiskinan; Pro-Poor Price Index; Price Index for the Poor
\end{abstract}

JEL classifications: E3; I3; O1; R2

\section{Introduction}

Most policymakers and economists agree that extremely high inflation has detrimental effect that will hurt the welfare of a society. It affects the economy negatively and reduces the purchasing power especially when the economy grows less than the inflation rate. On the other hand, several economists support the idea that moderate inflation rate is good for the economy (Marty \& Thornton 1995). Howitt (1990) then stated that society is better off to tolerate a little inflation than to bear a cost to achieve price stability.

* Corresponding Address: Ciumbueluit Street No. 94, Building 3, Parahyangan Catholic University, Bandung, Indonesia. Email: ruly .pratikto@gmail.com; ruly .pratikto@unpar.ac. id.
However, Shiller (1996) and Easterly \& Fischer (2001) argued that inflation is perceived by the lower income people as a serious concern, and it hurts them relatively more than it does on the nonpoor. As price increases, in order to hedge the negative impact of inflation, the rich would protect their wealth by investing in inflation hedge assets, i.e., bonds, stocks, and mutual fund. On the contrary, the poor do not have the luxury to protect themselves from inflation. It is because they are unlikely to have access to a relatively high interest-bearing assets, which usually requires a large amount of cash. The relatively higher risk of these assets also causes low-income people to avoid investing their money in it. They are not willing to risk losing their asset where small portion (if there is any) of their asset portfolios are likely to have a larger share of cash (Ikhsan 2010). 
Another concern that may have a substantial impact on poverty is the inflation differentials across commodities or services. Agenor, Izquierdo \& Henning (2007) stated that the poor tend to have different consumption pattern. They spend their income mostly on basic needs such as food and clothing. Thus, a higher inflation on those commodities would hurt the poor more than it would on the nonpoor. On the other hand, a hike of prices in luxuries would have little impact on them since they generally do not consume these goods. Therefore, inflation for the poor is most likely contributed by the price increase in necessities.

This matter becomes problematic since the most widely used of price indicator to calculate inflation is the Consumer Price Index (CPI). It uses the average budget shares of consumption as its weight to generate the CPI. However, this measurement does not capture the distributional impact of price changes, since it includes all class of income. In addition, it usually gives more weight to the urban household since it is generated by surveys in cities. Thus, since the poor tend to be concentrated in rural areas, their consumption pattern is not reflected in the CPI weight. As a result, the inflation rate calculated from the CPI also tends to undermine the total inflation rate experienced by the poor. Hence, the unequal impact of price changes.

Based on these arguments, it appears that inflation has unequal impact on people with different income level. This is particularly problematic for developing countries which are usually characterized by relatively high income-inequality. Thus, Son \& Kakwani (2009) developed a measurement that would systemically capture the impact of price changes on the poor relative to the non-poor, the so-called price elasticity of poverty, Pro-Poor Price Index (PPI) and the Price Index for The Poor (PIP). These methods are able to determine whether price changes in a particular commodity affect the poor more or less adversely.

In this study, by utilizing Son and Kakwani methods, we investigate whether unequal inflation has occurred in Indonesia, one of the developing countries where its income inequality has been widening (Yusuf, Sumner \& Rum 2013). Figure 1 shows the movement of inflation and the number and proportion of poor people ( $\mathrm{P} 0 /$ Headcount ratio) in Indonesia. Since the Asian Financial Crisis of 1998, Indonesia experienced a relatively low and stable inflation between 2003 and 2005. It was followed by a stable and continuous decline in poverty incidence. On the other hand, a hike in inflation in 2006 caused by a rise in fuel price increased both the number of poor people and the headcount ratio. Since then, Indonesia has returned to a stable and low inflation condition followed by gradual decreases in poverty headcount. In general, an episode of relatively high inflation was followed by an increase in both the number of poor people and the headcount ratio.

Indonesia uses the CPI to calculate the inflation rate. It is generated by surveys conducted by the Central Bureau of Statistics (BPS) in major cities in Indonesia, 66 of them as of 2013 (BPS 2013). Figure 2 presents the inflation rate of seven disaggregated CPI items in Indonesia between 2006 and 2012. It shows that food, processed food, and clothing commodities have been the major contributors to aggregate inflation.

Therefore, if those commodities are consumed relatively more by the poor, it appears that Indonesia's inflation rate has not been pro-poor. In other words, the poor has been facing inflation that is relatively higher than the non-poor. Thus, this paper also pursues to find which item of consumption that is important for the poor; the one that will hurt them more if its price increases.

Specifically, we determined the impact of price changes in several major commodities or services on poverty. We applied the price elasticity of poverty and PIP methodology on Indonesia both at national and regional (provincial) level since geographical and economic condition of Indonesia are very diverse across provinces. We sought to find any different characteristics of poverty concerning their response to any price changes in selected provinces.

In the remainder of the paper, Section 2 overviews the literature related to the impact of price changes on poverty, especially from the other countries experience. Section 3 provides the detailed description of methodology and data used in this research. In Section 4, we examine and discuss the empirical results. The last section subsequently provides the conclusion and policy implications. 


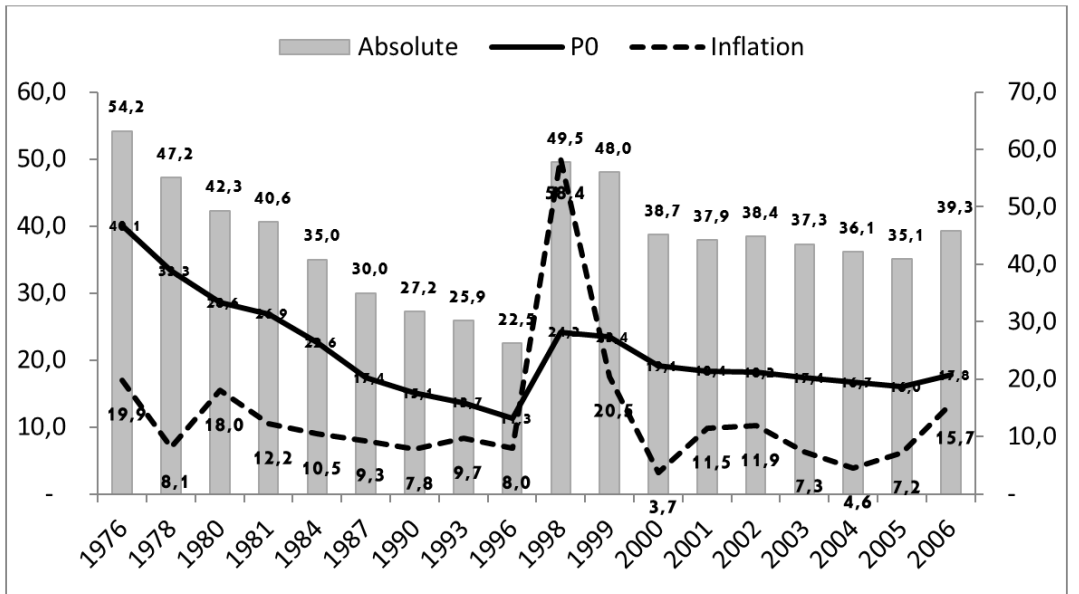

Figure 1: Inflation and Poverty in Indonesia (1976-September 2006) Source: Indonesia Central Bureau of Statistics and Bank Indonesia

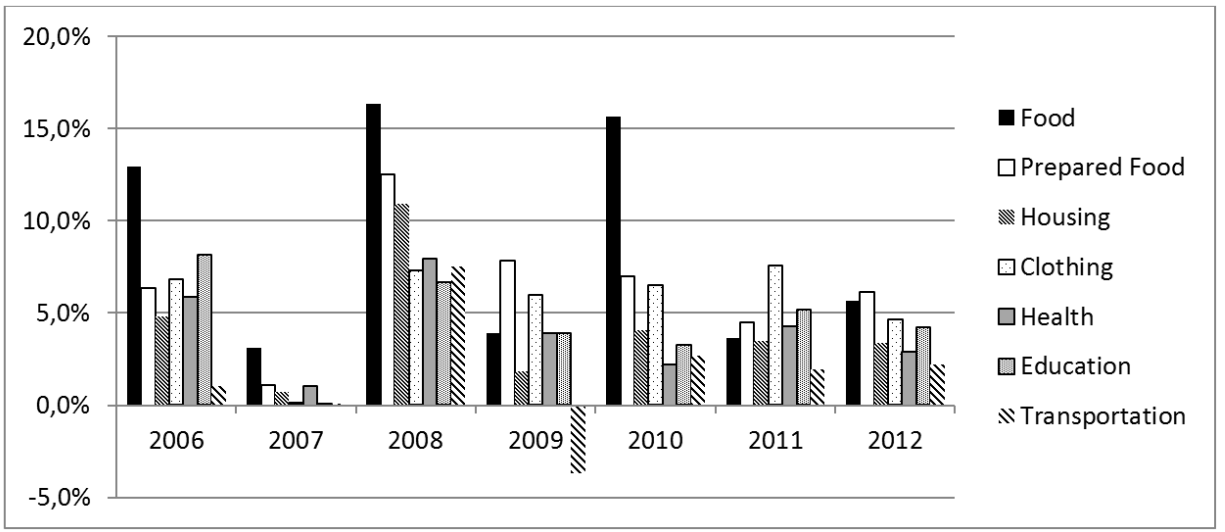

Figure 2: Disaggregated Inflation in Indonesia (2006-2012)

Source: Indonesia Central Bureau of Statistics 


\section{Literature Review}

A number of studies have been conducted to investigate the impact of inflation on poverty. The results mainly agree that inflation has negative impact on poverty. Easterly \& Fischer (2001) argued that inflation is "the cruellest tax of all" and it hurts the poor relatively more than the rich. By using pooling data in 38 countries, they found that the poor mentioned inflation as important national issue more likely than the rich did. They also found that the well-being of the poor was negatively correlated with inflation. Their finding was corroborated by Erosa \& Ventura (2002)who observed that the poor households held more cash asset than the nonpoor did. Thus, they concluded that the poor pay inflation tax disproportionately. In addition, Ravallion \& Datt (2002) by using household surveys in 15 India's states between 1960 and 1994 and utilizing panel data regression found that inflation had positive correlation with poverty.

These findings have encouraged policy makers to promote price stabilization policy in order to maintain their people's purchasing power, such as the inflation targeting adopted by several government central banks, i.e., Indonesia, New Zealand, Brazil, Israel, and the Philippines (IMF 2006). However, these results have not been considered an inflation inequality. Inflation will have different impact on a diverse population that has a heterogeneity of consumption pattern. The poor are likely to have different consumption patterns relative to the non-poor. Thus, an aggregate inflation that is contributed mainly by commodities consumed by the poor relatively more than the rich will have significantly different impact on poverty incidence. Hence, policies that stabilize aggregate inflation but not the commodity price consumed by the poor will not help them maintain their purchasing power.

Studies by Radhakrishna \& Ravi (1992) in India and Fujii (2011) in the Philippines seem to support this argument. They concluded that inflation hurts the poor more through food inflation, which was the main driver of inflation in their respective study. Thus, a price stabilization policy that is not effective in stabilizing food inflation will not help the poor. Agenor et al. (2007) in their study on the Brazilian economy stated that even though a permanent increase in central bank's official rate lowers inflation in the short term, it will lead to higher poverty rate. Thus, in order to formulate pro-poor price stabilization policy, policy makers should first identify which commodities that are imperative for the poor's wealth.

Based on this argument, Son \& Kakwani (2009) developed a methodology that will systemically capture the impact of price increase in different commodities on poverty. Using the definition of poverty by Foster, Greer, \& Thorbecke (1984), they constructed the Price Elasticity of Poverty, ProPoor Price Index (PPI), and Price Index for the Poor (PIP). Their empirical illustration in Brazil using household survey in 2002-2003 presented evidence that food, housing, and clothing were antipoor price index. That is, inflation in these commodities will have impact that is more unfavourable for the poor. They also found that price changes in Brazil from 1999 to 2006 had affected the poor more adversely. Their methodology, particularly the PPI, is a useful tool in formulating price stabilization policy, especially when the poor is of concern.

While the particular focus of this research is on the issue of unequal inflation, Son and Kakwani's methodology can have broader application. It also can identify the cause of the unequal inflation itself, whether it is pro-poor or anti-poor. In technical terms, the PIP serves as the proxy for the poor's inflation, while the Price Elasticity of Poverty and PPI can be utilized to detect the main source of the poor's inflation.

Thus, this study can give contribution to policy makers in Indonesia, especially those whose task is to stabilize price and formulate price stabilization policy that is pro-poor. In other words, price stabilization policy should focus more on commodities with higher price elasticity and PPI above unity (anti-poor price index). In the case of Indonesia, it is explicitly stated in the National Strategy for Poverty Alleviation/Strategi Nasional Penanggulangan Kemiskinan (SNPK) that the goal of this policy is to maintain the purchasing power of Indonesia, especially of the poor. 


\section{Method}

\subsection{Empirical Strategy}

In this research, we utilized the Son and Kakwani's (2009) methodology, the Price Elasticity of Poverty, Pro-Poor Price Index (PPI) and Price Index for the Poor (PIP) ${ }^{1}$. First, they defined poverty using the Foster, Greer \& Thorbecke's (1984) class of poverty measures $\left(\theta_{\alpha}\right)$ as follows:

$$
\theta_{\alpha}=\int_{0}^{z}\left(\frac{z-x}{x}\right)^{\alpha} f(x) d x
$$

where $z$ is poverty line, $x$ is individual income, $f(x)$ is a density function of individual income. Here, $\alpha$ is the parameter concerning inequality aversion. When $\alpha=0$, this measure was defined as headcount ratio that measures the proportion of poor people. For $\alpha=1$, each poor individual's income was calculated by how far it is from the poverty line, defined as poverty gap. When $\alpha=2$, it measures the income inequality among the poor and defined as severity index. To capture the impact of changes in price on poverty measures, they classified the Price Elasticity of Poverty into these three measures of FGT.

Firstly, the price elasticity of headcount was defined as:

$$
\eta_{H i}=-\frac{\partial H}{\partial p_{i}} \frac{p_{i}}{H}=\frac{z f(z) w_{i}(z)}{H}
$$

where:

$\eta_{H i}$ : price elasticity of headcount of commodity $i$; $H=F(z)$ : headcount ratio;

$f(z)=\frac{\partial H}{\partial z}$ : changes in headcount ratio for 1 -unit change in $z$;

$w_{i}(z)$ : budget share of commodity $i$ at poverty line

Equation (2) was interpreted as if price of commodity $i$ increases by $1 \%$, then the headcount ratio will rise by $\eta_{H i}$ percent. If all prices increase by $1 \%$, then Equation (2) becomes:

$$
\eta_{H}=\sum_{i=1}^{m} \eta_{H i}=\frac{z f(z)}{H}
$$

\footnotetext{
${ }^{1}$ Please refer to Son \& Kakwani (2009) for the complete derivation of the methodology.
}

Equation (3) was defined as total headcount elasticity, which measures the impact on headcount ratio when all prices increase by $1 \%$.

Secondly, to capture the impact of price changes on the other FGT's poverty measures, then:

$$
\begin{aligned}
\eta_{\alpha i} \quad & =\frac{\partial \theta_{\alpha}}{\partial p_{i}} \frac{p_{i}}{\theta_{\alpha}} \\
& =\frac{\alpha}{\theta_{\alpha}}\left[\int_{0}^{z}\left(\frac{z-x}{z}\right)^{\alpha-1} w_{i}(x) f(x) d x-\right. \\
& \left.\int_{0}^{z}\left(\frac{z-x}{z}\right)^{\alpha} w_{i}(x) f(x) d x\right] \\
& \text { for } \alpha \neq 0
\end{aligned}
$$

where $w_{i}(x)$ is the budget share of the ith commodity for every income level $x$. Thus, for $\alpha=1$, Equation (4) was interpreted as the price elasticity of poverty gap. It measures the percentage change in poverty gap when price of ith commodity increases by $1 \%$. Similarly, for $\alpha=2$, Equation (4) was interpreted as price elasticity of severity index.

When all price increases by $1 \%$, Equation (5) becomes:

$$
\eta_{\alpha}=\sum_{i=1}^{m} \eta_{\alpha i}=\frac{\alpha}{\theta_{\alpha}}\left[\theta_{\alpha-1}-\theta_{\alpha}\right]
$$

which shows the impact of price changes on poverty gap $(\alpha=1)$ and severity index $(\alpha=2)$ when all price rises by $1 \%$.

To identify whether price changes in commodity $i$ is have more adverse impact on the poor, Son and Kakwani defined a Pro-Poor Price Index, which is identified by:

$$
\varphi_{i}=\frac{\eta_{\theta i}}{\overline{w_{i}} \eta_{\theta}}
$$

where $\overline{w_{i}}$ is the average budget share in the $i$-th commodity in an individual's income. The $\varphi_{i}$ is interpreted as pro-poor if it is less than unity. Conversely, if it is exceeds unity, then a price change in commodity $i$ affects the poor more adversely than it does on the non-poor (anti-poor).

The price elasticity of poverty and PIP can be utilized to measure whether the actual inflation is propoor or not (ex-post analysis), which can be mea- 
sured by:

$$
\begin{aligned}
\sum_{i=1}^{n}\left(\frac{p_{i}^{*}-p_{i}}{p_{i}}\right) \eta_{\theta i}=\quad & \sum_{i=1}^{n}\left(\frac{p_{i}^{*}-p_{i}}{p_{i}}\right) \overline{w_{i}} \eta_{\theta}+ \\
& \sum_{i=1}^{n}\left(\frac{p_{i}^{*}-p_{i}}{p_{i}}\right)\left(\eta_{\theta i}-\right. \\
& \left.\overline{w_{i}} \eta_{\theta}\right)
\end{aligned}
$$

where $\left(\frac{p_{i}^{*}-p_{i}}{p_{i}}\right)$ is the percentage price changes of $i$-th commodity. The first term on the right hand side of Equation (7) measures the impact on poverty when all prices change at the same rate. It is the income effect of the price changes, and it will always be positive since an increase in any price reduces real income. The second term on the right hand side of Equation (7) measures the impact of changes in relative prices on poverty. It is the distribution effect of the price changes, and it can be either positive or negative. Price changes are pro-poor (anti-poor) if the second term is negative, which redistribute real income in favour of the poor.

In order to determine whether the poor has been facing a higher inflation rate, Son \& Kakwani (2009) also defined a Price Index for the Poor (PIP). Its straightforward definition is the price index experienced by the poor, which differs from the common Laspeyres Index (the CPI) from the perspective of whose price index it pertains to. The PIP was defined as:

$$
\lambda=\sum_{i}^{m} \frac{p_{i}^{*}}{p_{i}} \frac{\eta_{\theta i}}{\eta_{\theta}}
$$

Thus, the PIP can be compared to the CPI, and if the PIP is less than CPI, it can be interpreted that the poor has been facing a relatively lower price index. From the PIP, we also can calculate the inflation rate faced by the poor, which is the percentage change of the PIP. Afterwards, we can then compare the inflation rate of PIP to the inflation rate of CPI. If the PIP inflation is higher than the CPI inflation, it can be concluded that the poor has been facing higher inflation rate than the non-poor.

However, as stated by Son \& Kakwani (2009), their methods also have several limitations. One of them is that the method cannot detect the substitution effect of price changes. They argued that this is not the main problem of their method, since it is un- likely that the poor would change their consumption pattern significantly. Nevertheless, we tried to address this limitation by utilising their method in three base years, which is discussed in detail in the next section. The second limitation of these methods is that they do not consider whether the poor are the net producer of a particular commodity. It has been commonly argued that if the poor are the net producer, they will benefit from the price increase. However, Son \& Kakwani (2009) then argued that the price formation of a commodity differs at the consumer and producer level. Thus, this should be investigated in different matter. We also will discuss this limitation in the discussion and analysis section, and why it is not relevant to the Indonesian case.

\subsection{Data}

In conducting empirical illustration, we applied these methods on household survey data of Indonesia, the so-called National Socioeconomic Survey (SUSENAS). It covers detailed information of consumption expenditure of each household in the survey, both at national and regional level. In the analysis, we applied the national and regional poverty line constructed by the Indonesia Central Bureau of Statistics (BPS).

Our empirical illustration differed from Son and Kakwani's (2009) in Brazil regarding the use of the base year to calculate whether inflation inequality occurs (pro-poor or anti-poor). The purpose was to detect whether the poor changed their consumption pattern, which would be imperative in the policy implication. We utilized the 2007, 2009, and 2012 editions of SUSENAS and calculated their respective price elasticity of poverty and PPI. From there, we employed the 2007, 2009, and 2012 Indonesia Consumer Price Index (CPI) to analyse whether the inflation rate in Indonesia had been pro-poor or anti-poor. Afterwards, by using the same years, the regional/provincial analysis was also conducted.

There were two purposes of these time-series and cross-section analysis. The first was to investigate whether there were changes in consumption patterns of the poor over the years of analysis. Secondly, we sought to find whether there were any differences of poverty level responses with respect 
to price changes in different region in Indonesia. These two aims are important for the policy implication itself. If there is no alteration in consumption pattern and no differences of impact of price changes on poverty in each region, then the policy to control price itself will be uncomplicated compared to if there is any changes and differences. Conversely, if there are any changes in the poor's consumption pattern, whether at national or regional level, then the policy makers have to construct a tailor-made policy in order to efficiently eradicate poverty, in this matter through price stabilization.

\section{Results and Analysis}

\subsection{National Level}

Table 1 presents the calculation of the price elasticity of poverty and at the national level for three FGT's measures, i.e., the headcount ratio, poverty gap, and severity of poverty. We disaggregated it into seven categories of consumption commonly used in calculating the Consumer Price Index (CPI).

Headcount elasticity in food category means that a $1 \%$ inflation in food products would increase headcount ratio by $2.07 \%, 2.06 \%$, and $3.41 \%$ in 2007 , 2009 , and 2012, respectively. Similarly, the poverty gap would rise by $2.49 \%, 2.37 \%$, and $2.54 \%$ in 2007,2009 , and 2012, respectively, if food products inflated by $1 \%$. This relatively significant increase in food price elasticity of poverty over the years, especially for the headcount ratio, means that the poor had been extra sensitive when there were price changes in this product.

Moreover, even though processed food and housing price elasticity was relatively high, its PPI was well below unity. It indicates that the poor were affected less than the non-poor when the processed food and housing price was increasing, suggesting that the poor's relative spending on these commodities were lower than the non-poor. On the other hand, for clothing category in 2007 and 2009, its price elasticity for all poverty measures was relatively low but the PPI showed that inflation in this category would affect the poor more than the nonpoor. In 2012, clothing was no more an anti-poor price index since its PPI was less than unity. In addition, for the highest order of poverty measuresthe severity index-its elasticity was the lowest in all categories. It means that the ultra-poor were affected less adversely by the inflation compared with the poor with expenditure closer to the poverty line.

Moreover, the higher the degree of poverty measurement, the price elasticity was also higher. It implies that the ultra-poor were affected the most by inflation. This fact also corroborated Easterly \& Fischer's (2001) statement regarding the regressive impact of inflation. People with lower income would suffered the most by inflation.

Our result is partly similar to the empirical study of Son \& Kakwani (2009) in Brazil, where food and clothing constituted the anti-poor price index. However, our result differs with regard to housing and education price. They found that housing constituted the anti-poor price index, whereas we presented evidence that it was not the case in Indonesia. Furthermore, education in all years of analysis was an anti-poor index even though its elasticity was very low.

This evidence implies that although the impact of price changes in education on the poverty incidence was small, the non-poor benefited more than the poor did. Since July 2005, the Indonesian government has applied a program to support the education of Indonesians at least until the junior high school: the Bantuan Operasional Sekolah/School Operational Assistance (BOS), a policy that gives funds to schools to run their operation (Karisun 2010). Thus, no citizen of Indonesia has to pay the tuition fee and several other fees. However, this programme is dedicated to all citizens regardless of whether they are poor or not. Thus, since the non-poor have relatively high absolute income, their budget proportion for the education spending has become comparatively lower than the poor, making it more beneficial for them. Furthermore, since this policy applies only until junior high school level, once one of their family members goes to high school, the poor's budget proportion for education will exceed that of the non-poor family. Hence, the PPI of education that exceeds unity.

Another possible explanation related to the result of education price elasticity is the exclusion of poor household from state education. While the cost of education on state schools is controlled by the 
Table 1: Price Elasticity of Poverty and PPI National Level

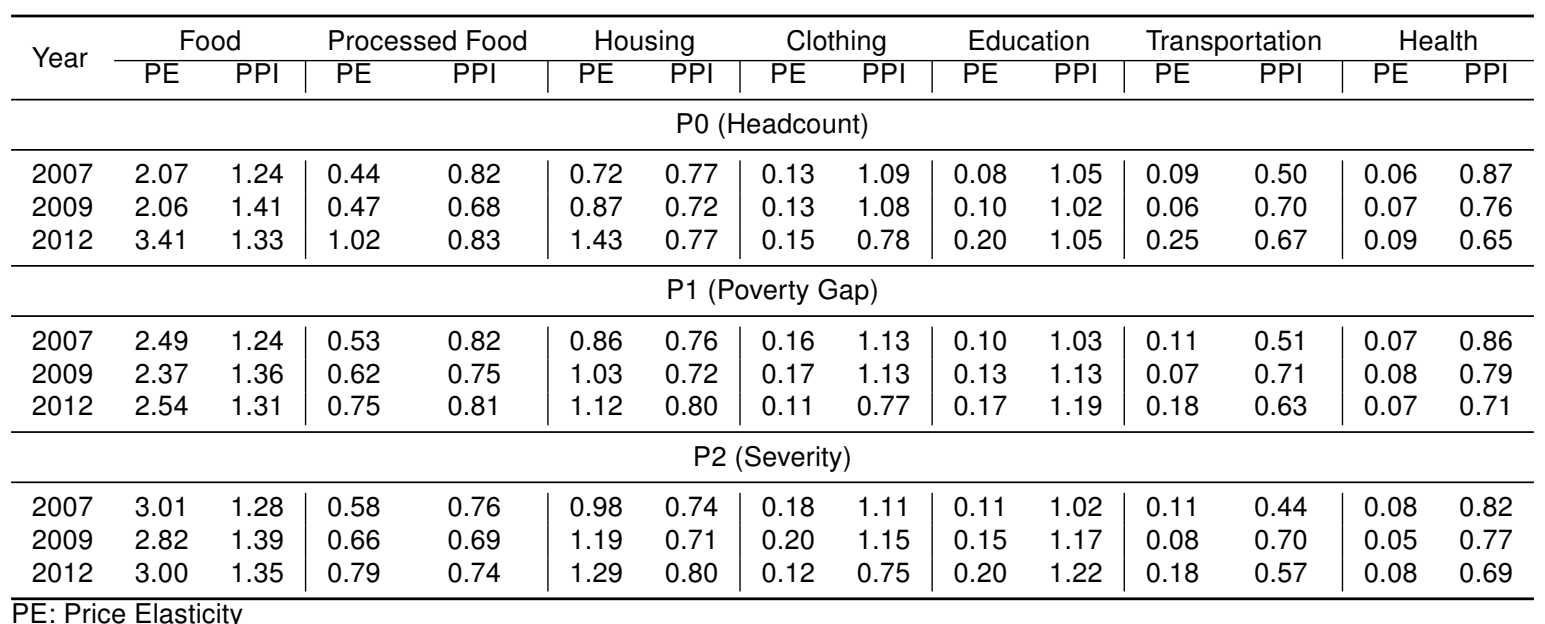

PE: Price Elasticity

Source: Authors' calculation

government through subsidy, private school tuition (which is not the main target of government subsidy) are increasing. As a result, the general price of education is also rising. So how has this impacted the poor's welfare? According to Darmaningtyas (2004), those who enjoy the government's education subsidy mostly are the non-poor. This is because of the low number of poor's participation in state schools, which might be caused by their low grades in previous level of education. Their low grades are caused by their limitation, such as in appropriate learning facilities, study time, and unsupportive environment. Thus, they do not have the prerequisite to enrol to state school. By enrolling in small private schools, they are obviously not enjoying government's education subsidy.

In general, we also found that there was an increasing trend of price elasticity of poverty over the years of observation, especially for food, processed food, housing, education, and transportation. It shows that the poor have become more sensitive to price changes in those commodities. There are several possible reasons on why those commodities constitute the anti-poor price index.

Firstly, the poor have been increasing their consumption proportion on those commodities. This is particularly true for processed food, housing, education, and transportation goods (Table 2). Secondly, price changes in those goods significantly increase the poverty line, which then result in sig- nificant increase in poverty. We argue that this was the case for food commodity. Even though the poor decreased their consumption proportion of food, these commodities contributed to approximately $59 \%$ of poverty line. Thirdly, it implies that the number of people who lived just above the poverty line was increasing. As a result, a proportional increase of poverty line in 2012 rose poverty incidents relatively higher than in 2007. This is corroborated by the BPS data. There was an increasing trend in the number of people living just above the poverty line. In 2012, these number doubled more than the number of poor people (Bappenas 2015).

This result also means that the poor have had different pattern of consumption relative to the nonpoor. Table 2 presents the weights for each of categories of consumption for the non-poor and the poor. The weights for the poor were derived from the price elasticity of headcount ratio (individual commodity elasticity relative to the total headcount elasticity), whereas the non-poor weights were calculated from SUSENAS data as an average of each category of consumption for those whose expenditure was above the poverty line.

It shows that the poor spent proportionately higher on food commodities and education significantly and consistently in all years of analysis relative to the non-poor. Moreover, budget weight for clothing was higher for the poor only in 2007 and 2009. These changes mean that not only the poor had 
Table 2: Consumption Weights for the Poor and Non-Poor National Level

\begin{tabular}{lcc|cc|cc}
\hline \multirow{2}{*}{ Category } & \multicolumn{2}{c}{2007} & \multicolumn{2}{c}{2009} & \multicolumn{2}{c}{2012} \\
\cline { 2 - 6 } & Poor & Non-Poor & Poor & Non-Poor & Poor & Non-Poor \\
\hline Food & $57.6 \%$ & $46.4 \%$ & $53.1 \%$ & $39.0 \%$ & $51.4 \%$ & $39.3 \%$ \\
Processed food & $12.4 \%$ & $15.1 \%$ & $14.0 \%$ & $18.6 \%$ & $15.2 \%$ & $18.8 \%$ \\
Housing & $20.0 \%$ & $26.3 \%$ & $23.0 \%$ & $32.1 \%$ & $22.7 \%$ & $28.5 \%$ \\
Clothing & $3.7 \%$ & $3.2 \%$ & $3.8 \%$ & $3.3 \%$ & $2.2 \%$ & $2.9 \%$ \\
Education & $2.3 \%$ & $2.2 \%$ & $2.9 \%$ & $2.5 \%$ & $3.4 \%$ & $2.9 \%$ \\
Transportation & $2.5 \%$ & $4.8 \%$ & $1.5 \%$ & $2.2 \%$ & $3.6 \%$ & $5.7 \%$ \\
Health & $1.7 \%$ & $1.9 \%$ & $1.8 \%$ & $2.3 \%$ & $1.4 \%$ & $2.0 \%$ \\
Source: Authors' calculation & & & & &
\end{tabular}

different consumption pattern relative to the nonpoor, they also altered their pattern over the years of analysis. Based on this evidence, we investigated whether the actual inflation rate in Indonesia in 2007, 2009, and 2012 had been pro-poor or anti-poor. Table 3 presents our estimates of percentage changes in poverty due to price changes (other factors remained constant).

Because of general price increase, the headcount ratio increased by $7.58 \%, 14.49 \%$, and $32.67 \%$ in 2007, 2009, and 2012, respectively. It also had greater impact on poverty gap, although the effect on severity was lower. We also decomposed it into income and distribution effect for all FGT's measures of poverty. The income effect measures changes in poverty as a result of counterfactual condition, that is, when all commodities are inflated by the same rate. Thus, the distribution effect (differences between total/actual change and counterfactual change) can be positive or negative. If it is negative, then the actual price changes are propoor, which means real income is redistributed in favour of the poor.

As can be seen from Table 3, Indonesia's inflation rate in 2007, 2009, and 2012 was not pro-poor. The distribution effect tells us whether changes in relative prices (across commodities/services) have affected the poor more adversely. We found that on a yearly basis, it was always positive. Thus, the poor had been facing higher inflation than the non-poor over those years.

To strengthen our conclusion, we also calculated the Price Index for the Poor (PIP) and its inflation. The PIP is useful to determine how much the inflation burdens the poor. We compared the PIP and $\mathrm{CPI}$ (and its respective inflation rate) to define whether the price index and inflation rate for the poor were higher/lower than for the non-poor. Table 4 presents the results.

The results show that the poor have faced both higher aggregate price and inflation rate in all years of study. Decomposition analysis shows that the food component was the main source of anti-poor inflation, except for 2009. In that year, even though the poor were still affected by higher price on food, the food inflation rate was relatively similar. On the other hand, both price index and inflation rate of non-food component were anti-poor. It is not surprising since in 2007 to 2009-as shown in Figure 2-the actual inflation rate for housing and transportation were relatively lower than other components. Since both were important commodities for the non-poor, this condition led to the non-poor facing a relatively lower non-food inflation rate in this period.

\subsection{Regional Level}

We also analysed the price elasticity of poverty and $\mathrm{PPI}$ in selected regions. As stated earlier, this part is important to determine whether there were different responses of the poor in respective provinces on price changes. If there were any differences, than the policy implication would be more complicated. The government should conduct a tailormade policy regarding price intervention. We selected the representative provinces based on their poverty incidence. In this regard, DKI Jakarta, West Java, East Kalimantan, and West Sumatra were representatives of provinces with relatively low poverty incidence (below national level). Gorontalo, South Sumatera, East Java, and Papua were representatives of provinces with poverty incidence above national level. 
Table 3: Percentage Change in Poverty due to Changes in Prices

\begin{tabular}{lccc}
\hline \multirow{2}{*}{ Period } & \multicolumn{3}{c}{ Headcount } \\
\cline { 2 - 4 } & Total Change & Income Effect & Distribution Effect \\
\hline 2007 & $7.58 \%$ & $6.62 \%$ & $0.97 \%$ \\
2009 & $14.49 \%$ & $14.47 \%$ & $0.02 \%$ \\
2012 & $32.67 \%$ & $31.17 \%$ & $1.49 \%$ \\
\hline \multirow{2}{*}{ Period } & \multicolumn{3}{c}{ Poverty Gap } \\
\cline { 2 - 4 } & Total Change & Income Effect & Distribution Effect \\
\hline \multirow{2}{*}{2007} & $9.12 \%$ & $7.96 \%$ & $1.16 \%$ \\
2009 & $17.51 \%$ & $17.23 \%$ & $0.27 \%$ \\
2012 & $24.62 \%$ & $23.60 \%$ & $1.02 \%$ \\
\hline \multirow{2}{*}{ Period } & \multicolumn{3}{c}{ Severity } \\
\cline { 2 - 4 } 2007 & Total Change & Income Effect & Distribution Effect \\
\hline \multirow{2}{*}{2009} & $10.44 \%$ & $4.65 \%$ & $0.79 \%$ \\
2012 & $14.14 \%$ & $10.02 \%$ & $0.06 \%$ \\
\hline Source: Authors' calculation & $13.54 \%$ & $0.60 \%$ \\
\hline
\end{tabular}

Source: Authors' calculation

Table 4: CPI and PIP Inflation

\begin{tabular}{ccc|cc}
\hline \multirow{2}{*}{ Period } & \multicolumn{2}{c}{ CPI } & PIP \\
\cline { 2 - 4 } & Index & Inflation & Index & Inflation \\
\hline \multicolumn{5}{c}{ Aggregate } \\
\hline 2007 & 155.28 & $6.57 \%$ & 155.56 & $8.83 \%$ \\
2009 & 177.81 & $7.25 \%$ & 183.43 & $8.96 \%$ \\
2012 & 205.48 & $5.19 \%$ & 221.63 & $6.94 \%$ \\
\hline \multicolumn{5}{c}{ Food } \\
\hline 2007 & 154.41 & $9.29 \%$ & 156.49 & $10.43 \%$ \\
2009 & 185.79 & $10.16 \%$ & 188.29 & $10.16 \%$ \\
2012 & 228.65 & $7.69 \%$ & 234.54 & $8.19 \%$ \\
\hline \multicolumn{5}{c}{ Non-Food } \\
\hline 2007 & 155.94 & $4.60 \%$ & 153.41 & $3.90 \%$ \\
2009 & 173.29 & $5.56 \%$ & 173.60 & $6.58 \%$ \\
2012 & 192.38 & $3.67 \%$ & 191.71 & $3.48 \%$ \\
\hline Source: Authors' calculation
\end{tabular}


Table 5: Price Elasticity of Poverty and PPI of Headcount for Regional Level

\begin{tabular}{|c|c|c|c|c|c|c|c|c|c|c|c|c|c|c|}
\hline \multirow{2}{*}{ Year } & \multicolumn{2}{|c|}{ Food } & \multicolumn{2}{|c|}{ Processed } & \multicolumn{2}{|c|}{ Housing } & \multicolumn{2}{|c|}{ Clothing } & \multicolumn{2}{|c|}{ Education } & \multicolumn{2}{|c|}{ Transport } & \multicolumn{2}{|c|}{ Health } \\
\hline & $\mathrm{PE}$ & PPI & $\mathrm{PE}$ & PPI & $\mathrm{PE}$ & PPI & $\mathrm{PE}$ & PPI & $\mathrm{PE}$ & $\mathrm{PPI}$ & $\mathrm{PE}$ & PPI & $\mathrm{PE}$ & PPI \\
\hline \multicolumn{15}{|c|}{ DKI Jakarta } \\
\hline 2007 & 2.49 & 0.78 & 1.17 & 1.12 & 2.32 & 1.28 & 0.19 & 0.84 & 0.23 & 1.50 & 0.37 & 1.11 & 0.14 & 1.07 \\
\hline 2009 & 1.44 & 0.85 & 0.94 & 1.17 & 1.40 & 1.01 & 0.14 & 0.99 & 0.11 & 1.04 & 0.21 & 2.27 & 0.08 & 0.76 \\
\hline 2012 & 1.98 & 0.89 & 1.21 & 1.14 & 1.73 & 1.07 & 0.11 & 0.65 & 0.31 & 1.90 & 0.28 & 0.87 & 0.06 & 0.51 \\
\hline \multicolumn{15}{|c|}{ West Java } \\
\hline 2007 & 2.38 & 1.10 & 0.70 & 0.99 & 1.07 & 0.87 & 0.20 & 1.29 & 0.12 & 1.14 & 0.13 & 0.56 & 0.09 & 0.98 \\
\hline 2009 & 2.24 & 1.28 & 0.72 & 0.86 & 1.06 & 0.73 & 0.19 & 1.24 & 0.14 & 1.24 & 0.09 & 0.88 & 0.07 & 0.67 \\
\hline 2012 & 2.69 & 1.16 & 1.10 & 0.99 & 1.45 & 0.86 & 0.13 & 0.76 & 0.22 & 1.28 & 0.21 & 0.64 & 0.09 & 0.79 \\
\hline \multicolumn{15}{|c|}{ East Kalimantan } \\
\hline 2007 & 4.21 & 1.10 & 0.96 & 0.77 & 2.30 & 1.06 & 0.22 & 0.84 & 0.21 & 1.14 & 0.25 & 0.61 & 0.11 & 0.70 \\
\hline 2009 & 2.39 & 1.31 & 0.57 & 0.66 & 1.40 & 0.94 & 0.11 & 0.73 & 0.12 & 0.98 & 0.20 & 0.16 & 0.05 & 0.46 \\
\hline 2012 & 2.25 & 1.25 & 0.56 & 0.66 & 1.27 & 0.97 & 0.06 & 0.46 & 0.15 & 1.13 & 0.23 & 0.87 & 0.06 & 0.60 \\
\hline \multicolumn{15}{|c|}{ West Sumatera } \\
\hline 2007 & 2.81 & 1.32 & 0.57 & 0.83 & 0.68 & 0.57 & 0.22 & 1.46 & 0.10 & 1.02 & 0.11 & 0.50 & 0.08 & 0.85 \\
\hline 2009 & 2.92 & 1.42 & 0.87 & 0.88 & 0.96 & 0.57 & 0.23 & 1.33 & 0.11 & 0.80 & 0.10 & 0.90 & 0.09 & 0.75 \\
\hline 2012 & 3.00 & 1.35 & 1.16 & 1.09 & 0.93 & 0.58 & 0.10 & 0.63 & 0.19 & 1.14 & 0.23 & 0.70 & 0.06 & 0.54 \\
\hline \multicolumn{15}{|c|}{ South Sumatera } \\
\hline 2007 & 1.90 & 1.58 & 0.34 & 0.60 & 0.55 & 0.63 & 0.09 & 1.02 & 0.06 & 0.65 & 0.07 & 0.39 & 0.04 & 0.69 \\
\hline 2009 & 1.78 & 1.45 & 0.36 & 0.61 & 0.73 & 0.82 & 0.10 & 1.10 & 0.06 & 0.72 & 0.04 & 0.25 & 0.04 & 0.64 \\
\hline 2012 & 1.62 & 1.42 & 0.38 & 0.69 & 0.61 & 0.73 & 0.04 & 0.50 & 0.11 & 1.28 & 0.11 & 0.69 & 0.04 & 0.60 \\
\hline \multicolumn{15}{|c|}{ East Java } \\
\hline 2007 & 1.92 & 1.24 & 0.40 & 0.79 & 0.71 & 0.81 & 0.12 & 1.13 & 0.06 & 0.84 & 0.06 & 0.38 & 0.06 & 0.94 \\
\hline 2009 & 1.92 & 1.33 & 0.49 & 0.71 & 0.95 & 0.79 & 0.15 & 1.19 & 0.10 & 1.02 & 0.03 & 0.35 & 0.08 & 0.99 \\
\hline 2012 & 1.14 & 1.11 & 0.31 & 0.94 & 0.53 & 0.91 & 0.05 & 0.69 & 0.07 & 1.46 & 0.07 & 0.70 & 0.04 & 0.88 \\
\hline \multicolumn{15}{|c|}{ Gorontalo } \\
\hline 2007 & 1.40 & 1.35 & 0.20 & 0.60 & 0.40 & 0.68 & 0.09 & 1.25 & 0.05 & 1.05 & 0.06 & 0.54 & 0.04 & 0.81 \\
\hline 2009 & 1.42 & 1.49 & 0.33 & 0.74 & 0.42 & 0.54 & 0.11 & 1.35 & 0.07 & 1.08 & 0.05 & 0.98 & 0.04 & 0.65 \\
\hline 2012 & 1.91 & 1.35 & 0.49 & 0.72 & 0.76 & 0.74 & 0.11 & 1.04 & 0.14 & 1.33 & 0.16 & 0.80 & 0.05 & 0.63 \\
\hline \multicolumn{15}{|c|}{ Papua } \\
\hline 2007 & 1.17 & 1.25 & 0.20 & 0.66 & 0.48 & 0.90 & 0.10 & 1.51 & 0.02 & 0.46 & 0.03 & 0.33 & 0.02 & 0.46 \\
\hline 2009 & 1.23 & 1.70 & 0.10 & 0.30 & 0.39 & 0.66 & 0.06 & 1.05 & 0.02 & 0.37 & 0.03 & 0.72 & 0.02 & 0.37 \\
\hline 2012 & 1.57 & 1.67 & 0.20 & 0.44 & 0.49 & 0.72 & 0.05 & 0.66 & 0.01 & 0.18 & 0.05 & 0.39 & 0.01 & 0.18 \\
\hline
\end{tabular}


Table 5 presents the price elasticity of poverty and PPI for the selected regional. This compact version excluded the price elasticity of poverty for poverty gap (P1) and severity index (P2), since there are no major differences between them concerning the PPI. We present the complete version in Table 6 and 7.

The result shows that there were no significant differences between provinces. Food was an antipoor index in all regions and years of analysis, except for Jakarta. This region had very different characteristics with regard to the PPI. The price elasticity of poverty in Jakarta region itself was similar with the other regions where food category had the higher elasticity. However, its PPI was less than unity over the years of analysis. It shows that food is a pro-poor price index in Jakarta, which means that inflation in this category will hurt the non-poor more. Nevertheless, its processed-food price elasticity was high and its PPI exceeded unity. Thus, we argue that we cannot rule out the imperativeness of food for the poor in this capital of Indonesia. Conversely, while in other regions transportation was not important for the poor, Jakarta had comparatively high price elasticity in this category and its PPI exceeded unity. Hence, inflation in transportation has been relatively sensitive for the poor in Jakarta as it had impact that was more unfavourable for them except in 2012. Similar to the national level, education was also essential for the poor in Jakarta.

Different poor consumption pattern in DKI Jakarta may arise from the demographic and social characteristics of this province. The poor in the other regions besides DKI Jakarta usually work in the agricultural sector (BPS 2013). Most likely, their work location is not very far from their home. Thus, the time spent for travelling from their home to their workplace is relatively short. Therefore, they have relatively spare time to prepare their own food, whether it is for breakfast or lunch. The case for DKI Jakarta is very different. A relatively far work location and bad traffic in DKI Jakarta make them have shorter time to prepare their own food. Thus, they spend more on processed food compared with the poor living in the other provinces.

Furthermore, for regions other than Jakarta, there are no significantly different characteristics relative to the national level regarding the PPI. In general, the poor who live in regions other than Jakarta are both vulnerable and affected more by inflation in food commodities.

However, there were particularly notable differences regarding the price elasticity of poverty. The price elasticity for food and processed food in Papua were relatively low compared with the other provinces. A straightforward interpretation is that the poor in Papua are more resistant if both commodities' prices increase. However, we argue that this is not the case. Firstly, the number of poor people (both in absolute and relative terms) in Papua are considerably higher than the other provinces. The price elasticity of poverty (Equation 2) mechanism shows that the higher the headcount ratio, the lower the price elasticity. It is also safe to say that the higher the headcount ratio, the lower the ratio of the number of people who live just above the poverty line compared with the number of poor people. Thus, a proportional increase in poverty line in Papua will increase the headcount ratio less than in the other provinces. Secondly, we also can interpret this number by the social and demographic character of the poor in Papua. The majority of them live in rural and remote areas. They normally consume food commodities from their own crops yield instead of buying them at the market. Hence, their expenditure on food commodities is considerably lower.

Moreover, the price elasticity of education in Papua was also significantly lower, and the PPI was also well below unity. This also can be explained by the poor's characteristics in Papua which are quite different from the poor of other provinces. Approximately $56.7 \%$ of household heads and $35 \%$ of child over the age of 15 years in Papua's poor households did not hold any certificate of education. Only $12.1 \%$ of them had Senior High School certificate (Bappeda Papua 2013). It implies that the poor households in Papua have very low spending on education, which subsequently results in low price elasticity of education and PPI below unity.

Another result on the regional analysis which has similar conclusion pertains to the sensitivity of poor people against price changes. Regions with relatively low headcount ratio tended to have higher price elasticity, especially on food price elasticity. This fact implies that even though the headcount figure is decreasing, Indonesia still has the problem of the number of poor people living just above the poverty line. Thus, proportional increases in 
Table 6: Price Elasticity of Poverty and PPI of Poverty Gap for Regional Level

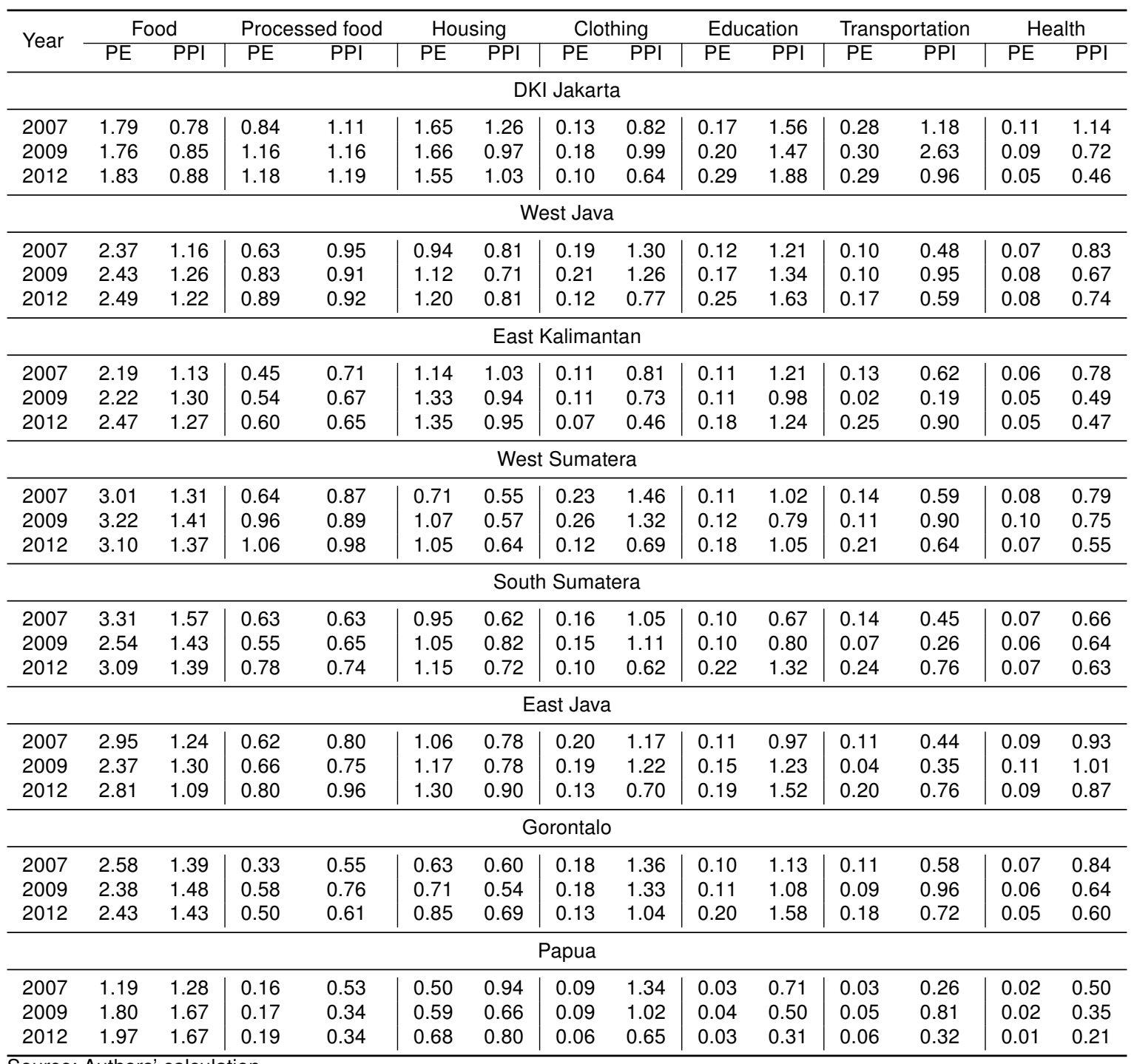


Table 7: Price Elasticity of Poverty and PPI of Severity for Regional Level

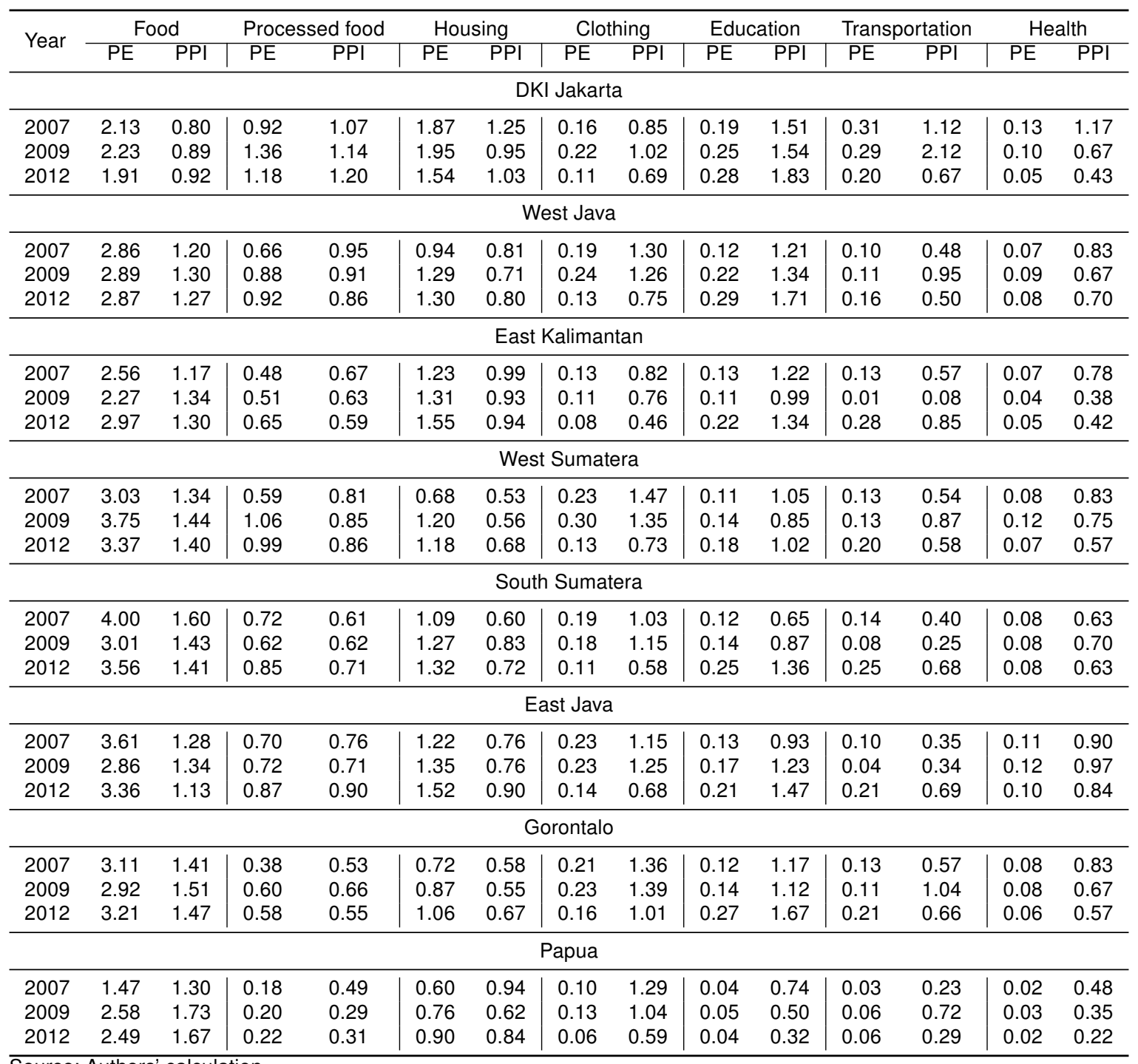


poverty line in provinces with low headcount will result in a higher increase in headcount figure ${ }^{2}$.

As stated in the methodology section, the limitation in the Son \& Kakwani's (2009) methodology is that it only considers the poor as the net consumer of commodity. One would argue that since the poor mostly work in agricultural area, an increase in food commodity would benefit them. However, Dartanto (2010) and Dartanto \& Usman (2011) in their study regarding poverty in Indonesian economy stated the fact that the poor are truly a net consumer of food commodity. Thus, an increase in food commodities would not benefit them, as also implied by the result of this research.

\section{Conclusion}

In this research, we have applied and calculated the Price Elasticity of Poverty, Pro-Poor Price Index, and the Price Index for the Poor along with their inflation rate. Our main objective is to investigate which impactful commodity is more adverse for the poor's wealth when there is a price change. By utilizing Indonesia National Socioeconomic Survey and Consumer Price Index in 2007, 2009, and 2012, our empirical outcome presented strong evidence that price changes in food commodity were not pro-poor. Our result also showed that at national level, inflation in clothing was anti-poor in 2007 and 2009, whereas education inflation was anti-poor in all years of analysis. However, their price elasticity was very low. Thus, we concluded that it diminished their imperativeness for the poor.

The ex post analysis at national level gave us estimate that the poor had been facing both higher aggregate price level and inflation over the years of analysis. It was mainly caused by the price of food that increased faster than the other commodities. Our results, particularly regarding the propoor price index, can act as a useful tool for the government of Indonesia in formulating their price

\footnotetext{
${ }^{2}$ Simulation using poverty line and headcount ratio in 2012 shows that a $10 \%$ increase in poverty line in DKI Jakarta and West Java, who has relatively low poverty figure, will rise the headcount ratio $74 \%$ and $46 \%$, respectively. On the other hand, a $10 \%$ increase in the poverty line in Gorontalo and Papua, who has relatively high poverty figure, resulted only a rise in headcount ratio as high as $29 \%$ and $15 \%$, respectively.
}

control policies. Since the poor are vulnerable to price changes, price policy in Indonesia should be made in favour of the poor. Here, stabilization policy for food price is vital when the poor's welfare is in question. Controlling for food price stability may thus greatly reduce poverty.

It is also corroborated by our result in regional analysis. Even though we found no major differences in the regional analysis concerning the pro-poor price index in which inflation in food commodity was antipoor, it had dissimilarity in the sensitivity of poverty responses on price changes. Formulation of propoor price stabilization policy in DKI Jakarta will be different from the other provinces. Controlling processed food and transportation inflation is more important and pro-poor in this province.

Moreover, there were also notable differences in poverty response on price changes in each province. The empirical evidence showed that inflation would increase poverty incidents relatively higher in the region with low poverty figures. It implies that even though Indonesia has been successful in reducing poverty, it still has problem of the number of poor people living just above the poverty line. Thus, this strengthens the imperativeness of price stabilization policy, especially for food commodities.

\section{References}

[1] Agenor, PR, Izquierdo, A \& Henning TJ 2007, Adjustment Policies, Poverty, and Unemployment: The IMMPA Framework, Blackwell Publishing Ltd., USA.

[2] Agenor, PR, Fernandes, R, Haddad, E \& Henning TJ 2007, 'Stabilization Policy, Poverty, and Unemployment in Brazil' in Adjustment Policies, Poverty, and Unemployment: The IMMPA Framework, PR Agenor, A Izquierdo \& Henning TJ, Blackwell Publishing Ltd., USA.

[3] Bappeda Papua 2013, Karakteristik Penduduk Miskin Provinsi Papua, Badan Perencanaan Pembangunan Daerah Provinsi Papua, Indonesia.

[4] Bappenas 2015, Strategi Peningkatan Pelayanan Dasar Bagi Masyarakat Miskin dan Rentan. Direktorat Penanggulangan Kemiskinan, Kementrian PPN/Badan Perencanaan Pembangunan Nasional.

[5] BPS 2013, Consumer Price Indices in 66 Cities in Indonesia (2007=100) 2013, Badan Pusat Statistik-Statistics Indonesia.

[6] Darmaningtyas 2004, Pendidikan yang Memiskinkan, Galang Press, Yogyakarta.

[7] Dartanto, T 2010, 'Volatility of World Rice Prices, Import Tariffs and Poverty in Indonesia: a CGE-microsimulation Analysis', MPRA Paper 31451, University Library of Munich, Germany. 
[8] Dartanto, T \& Usman 2011, 'Volatility of World Soybean Prices, Import Tariffs and Poverty in Indonesia', Margin: The Journal of Applied Economics Research, vol. 5, no. 2, pp. 139-181.

[9] Easterly, W \& Fischer, S 2001, 'Inflation and the Poor', Journal of Money, Credit and Banking, vol. 33, no. 2, pp. 160-178.

[10] Erosa, A \& Ventura, G 2002, 'On Inflation As a Regressive Consumption Tax', Journal of Monetary Economics, vol. 49, pp. 761-795.

[11] Foster, J, Greer, J \& Thorbecke, E 1984, 'A Class of Decomposable Poverty Measures', Econometrica, vol. 52, no. 3, pp. 761-766.

[12] Fujii, T 2011, 'Impact of Food Inflation on Poverty in the Philippines, SMU Economics \& Statistics Working Paper, (14-2011), Singapore Management University, School of Economics.

[13] Howitt, P 1990, 'Zero Inflation As a Long-Term Target for Monetary Policy', C. D. Howe Institute Working Paper, Toronto, Canada.

[14] Ikhsan, M 2010, 'Kebijakan Ekonomi Makro Khususnya Stabilisasi Harga dan Penanggulangan Kemiskinan', Pidato Pengukuhan Guru Besar Tetap Bidang IImu Ekonomi, Fakultas Ekonomi, Universitas Indonesia.

[15] IMF 2006, Inflation Targeting and The IMF, International Monetary Fund.

[16] Karisun 2010, 'Analisis Pelaksanaan Bantuan Operasional Sekolah (BOS) di MTs Negeri Wonosari Gunung Kidul Yogyakarta', Thesis, National Islamic University of Sunan Kalijaga.

[17] Marty, AL \& Thornton, DL 1995, 'Is There a Case for 'Moderate' Inflation?', Federal Reserve Bank of St. Louis Review, July/August vol. 77, no. 4, pp. 27-37.

[18] Radhakrishna, R \& Ravi, C 1992, 'Effects of Growth, Relative Price and Preferences on Food and Nutrition', Indian Economic Review, vol. 27, pp. 302-323.

[19] Ravallion, M \& Datt, G 2002, 'Why has Economic Growth been More Pro-Poor in Some States of India than Others?', Journal of Development Economics, vol. 68, pp. 381-400.

[20] Shiller, RJ 1996, 'Why do People Dislike Inflation?', Discussion Paper No. 1115, Cowles Foundation for Research in Economics, Yale University.

[21] Son, HH \& Kakwani, N 2009, 'Measuring the Impact of Price Changes on Poverty' Journal of Economic Inequality, vol. 7, no. 4, pp. 395-410.

[22] Yusuf, AA, Sumner, A \& Rum, IA 2013, The Long-Run Evolution of Inequality in Indonesia, 1990-2012: New Estimates and Four Hypotheses on Drivers, Center for Economics and Development Studies, Department of Economics, Padjadjaran University. 